\title{
Fairytale Authenticity: Historic city tourism, Harry Potter, medievalism and the magical gaze
}

\author{
By Dr Jane Lovell
}

\begin{abstract}
This article makes an original contribution to debates about authenticity by asking how tourist experiences of the medieval historic environment are linked to fairytales, providing a new way for tourists to imaginatively authenticate heritage. The architecture of some historic cities is preponderantly medieval, an era which is strongly associated with fairytales. Magical-historical double affectiveness has been compounded in the collective imagination by modern fairytales such as the fantasy Harry Potter and Game of Thrones which employ historic city locations and fauxmedieval settings, establishing a fluid magi-heritage simulacrum. This is concretised by the appearance in many historic cities of evidence of magical placemaking and staged magical authenticity, such as wizarding shops. The study used a visual methodology to examine fourteen historic cities including Oxford, Cambridge, Bath, York and Canterbury, demonstrating how the magical gaze employs fairytale schemata to imaginatively authenticate places. The findings illustrated how heritage tourists serendipitously encountered the medieval-fairytalesque, unfolding the agency of monumental cathedrals and castles and discovering stories and the historicisation of mythology within the extraordinary-ordinary streetscape. The research findings imply that in an era when the fantasy genre is increasingly popular the experiential authenticity of heritage tourists may be enhanced by the "heritage marvellous."
\end{abstract}

\section{Keywords}

Authenticity, historic cities, heritage tourism, magic, fairytales, medieval.

\section{Introduction}

This article makes an original contribution to debates about heritage authenticity by exploring authentically imaginative experiences, defining magical realities and linking the medieval historic environment to fairytales. The research question examines the ways in which the marvellous manifests in tourist experiences in historic cities, many of which are illuminating case studies when discussing authenticity because the historic environment contains a substantial amount of original and pastiche medieval heritage (Tuan, 2001). The medieval era continues to remain a popular object of fascination (Eco, 1986, p.68) and is strongly associated with fairytales (Ortenberg, 2006). Fairytales continue to evolve; recent fantasy texts include the books and televised adaptations of A Discovery of Witches by Deborah Harkness and His Dark Materials by Philip Pullman, both filmed in 2018, which converge in parallel fantasy and heritage versions of the historic city of Oxford. These fantasies use settings of castles, alleyways and landmarks which possess significant historical 'architectural agency' (MacDonald, 2009, p.157) such as the Bodleian library. In contrast, dramas like Game of Thrones remodel the medieval era by historicising mythology in a genuine and faux pastiche settings and tropes (Larrington, 2016).

Capital cities such as New York or London have been denoted 'cinematic' (Shiel and Fitzmaurice, 2001) and some tourists feel that heritage sites resemble movie sets (Willson and MacIntosh, 2007). This study was initiated because when researching the extent of staged authenticity in historic cities, rather than the sensation of being on a film set, unexpectedly, heritage tourists conveyed the feeling of inhabiting a fairytale. The implications for research and practice are that with a plethora of gaming, film and TV fantasy influences, tourists may increasingly encounter a blended "heritage marvellous" or "magi heritage" in historic cities. Magical placemaking may augment the spectrum and quality of visitor experiences, by expanding the opportunities to imaginatively authenticate the historic environment.

\section{Literature Review}

\section{Magical realities}


A key element of this paper demonstrates how magic and fairytales can be applied to heritage, tourism and authenticity. Magical reality was first used to describe post-colonial Latin American literature, juxtaposing the technological magic of the new world and the functional spirituality of the old (Faris, 2004). To deconstruct magical reality further, according to Bowers (2004, p.20): ' ...in marvellous and magical realism "magic" refers to any extraordinary occurrence' and realism is what can be 'detected through the senses.' While the phrase magical reality suggests polarity, Faris (2004, p.1) resolved the duality by stating that magical reality combines a perceptual: '... realism and the fantastic, so that the marvellous seems to grow organically within the ordinary, blurring the distinctions between them.' In the same vein, Strecher (1999, p.267) brought the separate elements of magic and reality together by outlining the '...marvellous-yet real-place' drawing on Russia's literary tradition of the maravilloso (the marvellous real). These definitions encapsulate the paradigm used in this article, where magical realities embody the imagination (including wonder, the extraordinary, marvellous, fantastical and fairytalesque) and reveal the "heritage marvellous" or "magi-heritage" in the actual world.

Parallels exist between tourism, authenticity and magic. The drive to fulfil a fantasy or unobtainable quest (Crang, 1996, p. 415; Knudsen, et al., 2016) motivates tourists seeking 'experiential authenticity' (MacCannell, 1976; Wang, 1999). Folklore tourism is regarded as a sub-set of heritage tourism that offers tourists something 'beyond the ordinary' (Timothy, 2011, p.424) and the desire to escape the everyday and experience the fantasy could be said to underpin much tourism activity (MacCannell, 1973). Leal (1995, p.101) submitted that magical realism is ' .... an attitude toward reality' and postmodern authenticity (Wang, 1999) is supposedly a more playful viewpoint which is substantiated by the tourist pursuit of imaginary worlds and enchantment (Hennig, 2002; Robinson and Picard, 2009). Authenticity is an applicable concept in themed magical environments; Waysdorf and Reijinders (2018) and Lovell and Bull (2017) observed how tourists authenticate the Wizarding World of Harry Potter, for example using the theme park's "official" endorsement by JK Rowling.

Transformational authentic experiences are sought at living history sites, re-enactment festivals, cosplay events and at fantasy film locations (Beeton 2016; Buchmann et al. 2010, Carnegie and McCabe, 2008; Everett and Parakoottathil, 2018). Kim and Jamal (2007, p.198) implied that during these activities, tourists construct an 'alternative reality.' This research suggests that rather than tourists adopting alternative realities, medieval historic environments stimulate tourists to perceive magiheritage as the embodiment of the imagination in the actual world.

Authenticity is a liquid term and it is important to contextualise its use. It could be argued that in addition to postmodern authenticity, objective authenticity (Wang, 1999) often employed by heritage tourists resembles the magical in its focus on the auratic, cultic qualities of remoteness, value and rarity (Benjamin, 1936, 2008). When also researching authenticity, Rickly-Boyd (2012, p.129) remarked on the use of the word 'magic,' used by tourists to describe the wonder of heritage reproductions. The elusiveness of aura means that while people travel to find it, it remains everfugitive and yet exerts a magnetic force. Chhabra's (2010, p.806) work on Generation Y indicates an interest in object-related authenticity rather than theme parks, preferring 'true to the original and historically endorsed objects.' Thus, Generation Y are more likely to visit the auratic material architecture of historic cities, however, once there, the proximity of heritage may evoke magical qualities. Magical realities have been positioned by Lovell and Bull $(2017$, p.8) within debates about authenticity, suggesting that tourists both attribute magical qualities to places and also experience places in magical states including the 'dreamlike, poetic, otherworldly, rescaled, phantasmagorical and uncanny.' They extended Fjellman's (1992, p.255) descriptors of Walt Disney World: 'fake fake, fake real, real real and fake fake,' to include the unreal, hyper real and magically real. While resembling the inversions, copies and exaggerations of hyperreality (Baudrillard, 1981; Eco, 1986), magical realities differ, within this paper, because they are underpinned by stories. Building further on conceptual intersections, fairytales have been defined by Swann-Jones (1995, p.9) as encompassing any story incorporating the magical or marvellous. For the purposes of this research, magical realities, marvellous realities, and the fairytalesque are viewed as permeable terms, encapsulating the fantasies which tourists seek. 
The 'Fairytale Route' in Germany (Bendix and Hemme, 2004; Hemme, 2005) is a popular fantasy tourist destination, as are folklore festivals and re-enactment events. Storytelling has always been perceived as an essential aspect of historic interpretation, and fairytales provide recognisable schemata which enable tourists to relate to the past (Smith, 2006). Fairytales are significant to tourism (Järv, 2010); Larrington (2015, p.7) observed how people are attracted to: 'tales which draw their energy from the places where we live or where we travel.' Some tourists seek to understand the myths of origins of places (Lovell and Bull, 2017) and Larrington (2015, p.9) argued that legends offer answers '...through a kind of metaphorical thinking, through structures and patterns which, in their stripped-down clarity, show us what's really important in an unfamiliar light.' Larrington went on to describe (p.16-30) how Anglo Saxons explained the ruins of Roman buildings in Britain as the work of giants, demonstrating how multi-layered historic environments have traditionally been explained by fairytales. It has been demonstrated by Lovell and Bull (2017) that heritage tourists coolly use facts to 'mechanistically authenticate' historic sites. When tourists 'imaginatively authenticate' medievalness with fairytales, they may also make meaning and attribute origin stories in a warmer, more playful postmodern manner.

As part of the process of authentication, historic cities are framed by a 'magical gaze' which takes Urry's (2002) original, romantic 'tourist gaze' further into the realm of the imagination. Historic cities are inchoate canvases, peppered with material and atmospheric traces of the Roman and medieval landscape, in which tourists can detect the poetic 'reverberations' (Bachelard, 1994) of the past. Fairytales help the process of reconstructing the past, by entwining collective memories with the collective imagination in a simulacrum of medievalness. Historic and film re-enactors actively pursue experiential authenticity: 'Both require accurate foundations; it is only when their two worlds are aligned that their fantasy performances can take place' (Lovell and Bull, 2017, p.155). Heritage tourists may unexpectedly encounter magical realities due to factors such as the resonance of historic sites, the vertiginous abstractness of the past and its materialisation in monumental structures such as city walls. The auratic encounter with vestiges of the distant past may seem a source of wonder to the 'imaginative eye' (Massey, 2005) and a state of 'heritage flow' merge with a 'magical flow' (adapted from Lovell and Bull, 2017, p.11). Rather than a reading of historic cities as texts, a state of magical flow unfolds the extra-textual, 'the inside of the outside or outside of the inside' (Derrida, 1976, p. 32). Openness to the imagination is necessary for tourists to experience the creativity and fluidity of space and poetics (Barthes, 2000; Bachelard, 1994; Massey, 1995; Relph, 1976; Tuan, 1991). Flow also necessarily absents the gazer, who adopts the 'imagining attitude' (Sartre, 2004, p.190), which is assumed when mentally recreating the stories within the composition of paintings, or when reading fiction. Magical realities are described by Lovell and Bull $(2017, \mathrm{p} .8)$ as an 'evaporating' rather than a hot form of authentication, because of this abstraction of the imaginative experience. When magic and reality are aligned in historic cities, the imagination is allowed to unfold marvellous realities.

\section{Once Upon a Time in Historic Cities - Magical Placemaking}

Historic cities have long been considered as significant tourist destinations; Ashworth, and Tunbridge defined the term 'tourist-historic city' (2000), emphasising the issues of congestion and commodification which epitomised over-tourism in the historic cities of the early 1990s. They are meaningful sites in which to study authenticity, incorporating the ongoing tension between preservation and development. The layout of historic cities may vary, but tends toward a physically compact palimpsest of different built eras, with a Roman grid plan, and walls and a winding medieval cluster of streets centred on a cathedral or church (Orbaşli, 2000, p.9). While the built heritage of historic cities is seemingly static and immutable, the city walls, cathedrals, castles, timbered buildings, narrow lanes and jetties and cod-medieval new builds are also soft, phenomic places of legend and memory (Nora 1992; Smith, 2006). The material heritage environment provides visual metaphors such as ruins, which allow tourists to displace the present and mentally reconstruct the past. Official versions of authentication, such as World Heritage Centre designation in Bath, 'frame and elevate, enshrine and reproduce' (MacCannell, 1976, p. 43-45) as part of the sacralisation process, enfolding physical buildings in a magical envelope of constructed authenticity. 
Intangible cultural heritage is nurtured by historic cities because it contributes extraordinary, locally distinctive elements to the cultural capital. In 2005, a report, City of Imagination (Yellowbook, 2005), emphasised Canterbury's links to authors such as Geoffrey Chaucer. It could be said that historic cities invent traditions (Hobsbawn and Ranger, 1983) which embellish and augment elements of the fairytale-medieval; designing medieval parades and pageants, generating historic simulacra and reinventing old mythologies. Lovell and Griffin (2018) have argued that light installations and festivals, such as Durham Lumiere, are magically real and irreal events, using illusion to encase immanent historic structures, evoking affective atmosphere and sensations of disbelief and wonder and attracting fairytale tourism (see image 1).

Image 1: St Augustine's Abbey Light Installation, November 52018

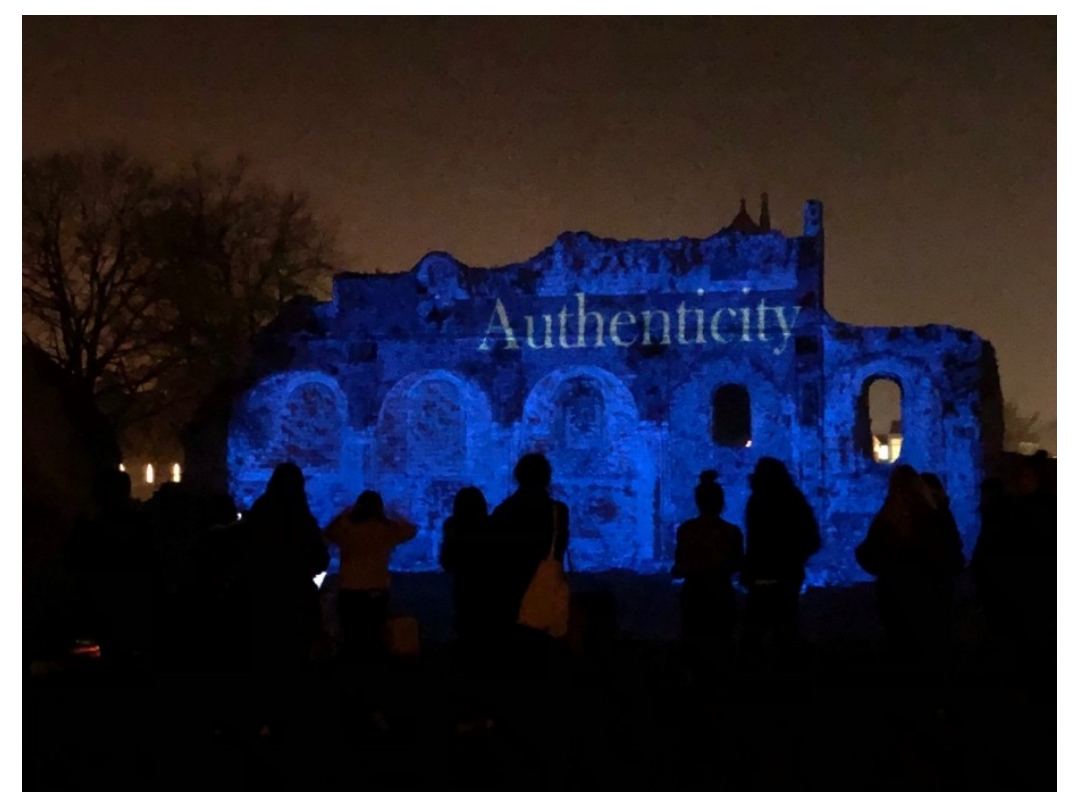

Placemaking builds on the monumental and vernacular architecture of historic cities which is primarily connected with the medieval period (Relph, 1976). This era is specifically associated with folklore according to Ortenberg (2006, p.40): 'The literature of folklore, of which fairytales were regarded as an essential component, went hand in hand with scholarly interest in the medieval past.' Debord (2014, p.74-75) made the point that while belief in myth ended with the Middle Ages, the Middle Ages has become a mythic period of history. In the essay, Dreaming of the Middle Ages, Eco (1986, p.66) asserted that: 'immediately after the official ending of the Middles Ages, Europe was ravaged by a pervasive medieval nostalgia' which, he argued, continues today. New generations of tourists are emerging for whom Zipe's (1988, p.148) declaration that fairytales 'pervade our lives' is highly relevant. That historic cities embody fantasy culture was evident in Will Self's description of Canterbury at a book reading in Canterbury in 2007: "It is Hobbiton."

This fairytale-medievalness is symptomatic of the emergent, constructive and postmodern authenticity (Bruner, 1994; Cohen, 1988; Wang, 1999) reflected in cyclical social taste and the metahistorical. Collective memory is a selective, unreliable narrator, focusing on popular eras of history such as medieval and Roman (Eco, 1986) and tending toward the sensationalism of 'mythhistoricus' (Cornford, 2014) which blends history and artistry in the telling. Eco (1986, p.63-65) observed that the medieval is on 'continuous return,' but it is the spectacularly medieval which is repeated in trends such as pre-Raphaelitism. Historical storybookism was treated in an acerbic manner by Benjamin (cited in Boyer, 1996, p.135), who remarked that: 'once upon a time...resides in the brothel of historicism.' The mid-to-late Victorian revival of fairytales portrayed a heightened, romanticised version of the faux-medieval, associated with artisanship and authenticity. Ultimately, 
according to Eco (1986, p.67), 'the rediscovery of the medieval would be the work of twentieth century mass-media.'

Some mass-media reinterpretations of historic themes extended postmodern authenticity and provoked some critics to cite 'fakelore' (Crang, 1996, p. 429) and ultimately, 'Distory' or 'Disney realism' (Fjellman, 1992, p.60). Eco (1986, p.67) described medieval pastiche as 'fantastic neomedievalism,' which is exemplified by the spectacle of Game of Thrones (2011-), blending medieval European history with the Celts, Anglo-Saxons and Vikings (Larrington, 2016). The potential effect of fantasy on heritage tourism is suggested by the recent explosion of films and television series about the supernatural addressed earlier. Growing numbers of media platforms, games such as Assassin's Creed, the increasingly sophisticated use of virtual and augmented realities and special effects square the 'hermeneutic circle' (Jenkins, 2003) of medievalism. Mixed realities are not simply technological, but imaginative. Fairytales also continue to evolve as living traditions using intertextual referencing and formats, for example the artwork of Paula Rego, and the Game of Thrones tapestry in Ulster, feeding the collective imagination and potentially leading to the reappraisal of medieval sites by tourists.

Magical placemaking, which historicized mythology, has occurred in some historic cities. Connections to fantasy can be tangential, for example, even urban myths about the ubiquitous modern fairytale, Harry Potter add locations to guided tours: key historic alleyways in London, York, Exeter, Edinburgh and Chepstow all share the title of the "inspiration for Diagon Alley." The wizarding establishment, The Shop With No Name opened in 2017 in the Shambles in York as a result attracting several others and there are wizarding shops in Edinburgh, including The Boy Wizard and Diagon House in Victoria Street. These historic cities follow Kings Cross's Platform Nine and Three Quarters in the move towards staging extra-textual, physical versions of the Potterverse. Oxford is a fulcrum of magical geographies, with tours of Harry Potter filming locations, the parallel realities of Lyra's Oxford and Narnia, plus growing interest in the sites of the book and televised adaptation of The Discovery of Witches. The tour guides mix factual heritage and fantasy content when visiting sites such as the Pitt Rivers Museum (Coffrey, 2017). Canterbury Cathedral was selected as the original location for Hogwarts in the Harry Potter films, but eventually Gloucester and Durham Cathedrals, Alnwick Castle and Lacock Abbey acted as an assemblage of the wizarding school. Regardless of which cathedrals were chosen, Harry Potter contributed to the lexicon of magi-heritage turrets, gothic halls and cloisters, let alone mysterious alleyways, crooked buildings, rambling pubs, and cobblestones. This article investigates how the built medieval (and neo-medieval) heritage of historic cities may be authenticated by tourists as innately magical, prior to placemaking.

To conclude this section, Eco (1986) listed ten contemporary versions of the Middle Ages and if an eleventh were added today, it may be entitled: 'The fairytale-neomedieval tourist destination.'

\section{Methodology}

The research employed a visual methodology, which is appropriate because photography has been described as a way of making magic (Picard and Robinson, 2009). Larsen (2008, p.149) argued that photography is an organic way of processing experiences and Visitor-Employed Photography (VEP) (Dodman, 2003) emerged as a sensory, self-directed research tool, permitting the mobility essential for a spatial study of tourism. Using photography enabled participants to perform a placemaking and storytelling activity of their own (Pink, 2006). An initial VEP study into authenticity was conducted in 2009-10. This foundation was extended into a longitudinal study and further data collected in September 2016 and June-August 2018 through semi-structured interviews with tourism and heritage practitioners. A convenience sampling strategy was adopted which involved approaching placemaking experts, obtaining the views of an informed research population. The VEP study distributed disposable cameras and diaries (photo-diaries) to tourism managers from the historic cities of Bath, Brighton, Cambridge, Canterbury, Chester, Chichester, Durham, Lancaster, Lincoln, Oxford, Rochester, Shrewsbury, Winchester and York. It is worth noting that this study involved English historic cities, but the findings are equally internationally applicable. 24 placemakers have also taken 
part, (including archivists, stonemasons, architects, development managers, planning officers and museum curators). In total, 64 tourists from Canterbury were chosen using the pragmatic criterionbased sampling on arrival at the Visitor Information Centre. Pseudonyms are used to protect the anonymity of participants. This established a representative range of participants from all ages and 23 nationalities, while it is a small sample of the approximately approximate 4.2 million tourists visiting the city. The Visitor Information Centre not only legitimised the project but allowed easy, city-centre return of the camera packs. Altogether, 1203 photo-diary entries have been assessed. While disposable cameras are dated, the retro method caught the attention, increasing the likelihood of a significant response.

Participants were asked: 'To what extent is this place authentic or inauthentic?' and Lightroom software provided a method of searching and theming, intertwining image and text equally, to further understand the phenomic, experiential meaning of the photo-diaries (Pink, 2006) (see image 2).

Image 2: Lightroom software displaying Sir John Boy’s House in Canterbury.

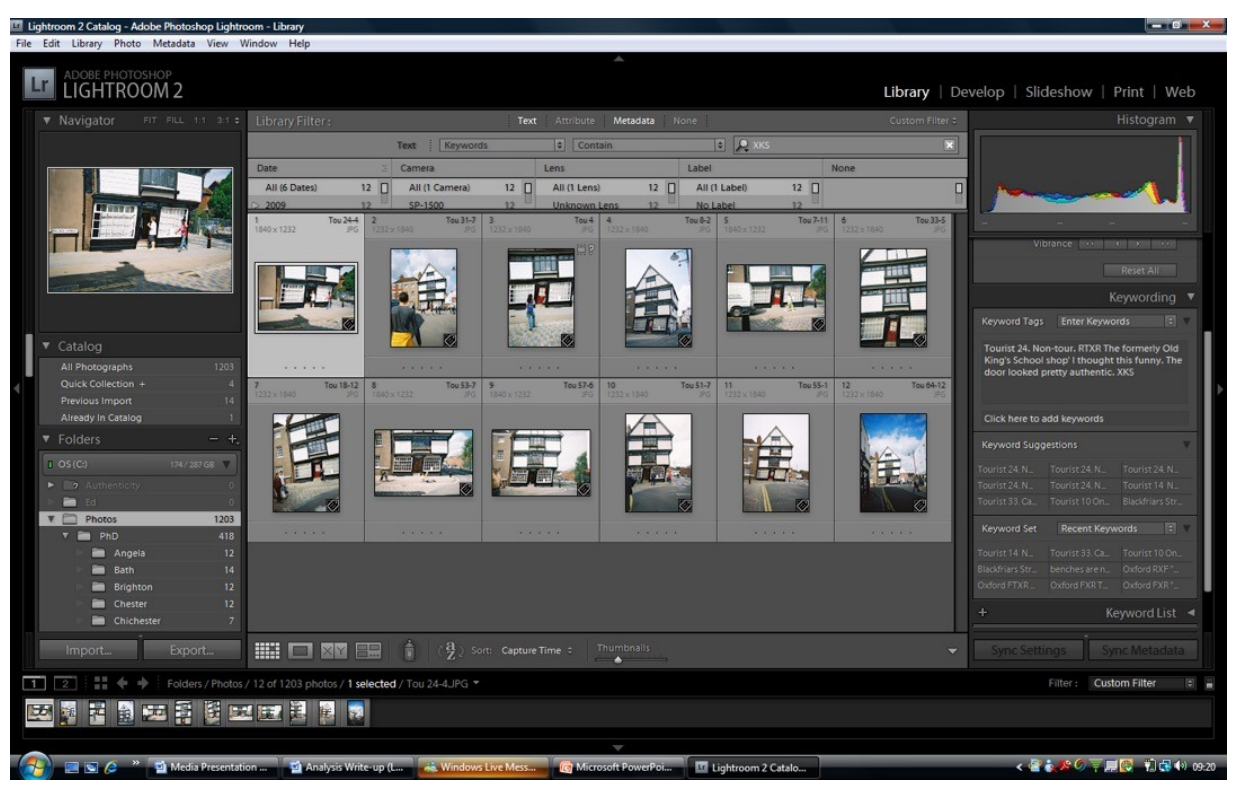

After pure content analysis (counting castles) was deemed overly quantitative for a visual approach, the method of assessing the photo-diaries strove for a richness and depth appropriate for a qualitative study. The four-stage method developed by Collier (2001) suggested that the researcher worked from the individual photographs upwards. This meant that rather than working with 98 participants, the researcher was working with 1203 views of historic cities. To establish coherence, the researcher used the structure of Fjellman's (1992) categories of fake and real to reassemble the historic cities into four typologies.

The longitudinal study has explored a 'participatory' (Guba and Lincoln, 2008, p.192-197) paradigm, recognising the 'interweaving of viewpoints, for the incorporation of multiple perspectives.' Different perspectives are inherent in visual methodologies; the possibility of attribution is recognised at various stages of the process, including the interpretation of the photographer and the subjectivity and reflexiveness of the researcher (Stevenson and Inskip, 2008). To emphasise the co-creation, 'studium' (Barthes, 2000, p.20-28) was employed to avoid photographs being 'inert' or 'polite' under the researcher gaze, by animating images with the agency of 'affective intentionality.' Using the practice of studium - perhaps a magical form of deeper analysis - a grouping emerged from the categories of fake and real as a fairytalesque assemblage of magical realities and formed the inspiration for the article. 


\section{Findings}

\section{Gingerbread spaces in Wonderland}

The research findings focused on three aspects of magical realities: the suggestions and affordances of material heritage, the relationship of tourists and placemakers to unseen 'medieval hosts' and mythhistoricus, or performed, staged medievalness.

That the architecture of historic cities yields medieval and magical atmospherics, was remarked on by participants visiting Canterbury, for example, Tourist 43: "Everything is magical" and Tourist 27: "I like the medieval feeling of the city." The medieval era was by far the most popular epoch mentioned in the study. The miracles (and fakery) worked on pilgrims visiting the shrine of the murdered Thomas Beckett, arguably give Canterbury an enduring magical atmosphere and tourists visiting the city with this in mind may predisposed to the marvellous. As sites of meaning, historic environments can incline visitors towards storytelling, for example Stevenson and Inskip, (2008) described the semiotic power of clock faces and after moving to the city, a tourism practitioner (Canterbury 16), was struck by the "storybook" blue clock faces on heritage buildings.

The heritage environment portrayed in the photo-diaries seemed to the researcher to unfold and fold in a Derridian manner as visitors observed the built streetscape. Spatial fairytales were suggested by the depth of photographic compositions, where narrow streets and lanes and jetties loomed over the observer. The effect created a Tom Thumb perspective, shrinking the viewer in a giant environment, where the tall buildings returned the gaze. Monumental medieval structures were designed to dominate (Relph, 1976); cathedrals, castles, towers, and city walls were constructed to fortify cities and convey temporal and spiritual power, underlining how: 'the castle is so marvellous a place of human design, that marvels seem especially suited to it' (Thomas, 1986, p.129). Multiple photo-diary entries of St George's Clocktower in Canterbury and Clifford's Tower in York. Towers are tropes of fairytale settings (Thomas, 1986) follies in the city, from which Rapunzel could let down her hair. It is not only the medieval, but also Gothic and Neo-Gothic architecture which celebrated a storybook feel during Romantic revivalism. Photo-diaries expressed the overwhelmingly "wonderful," "marvellous" and "really real" impressions of the Gothic spires of cathedrals and Kings College chapel Cambridge. Winchester was said by the practitioner to be a "city of gates" with primarily symbolic resonance due to their position in the city centre as fragments of a vanished boundary. Some photo-diaries featured the river through the bars of the fence, or the churchyard glimpsed through a wooden gate, unfolding an innately romantic, Gothic narrative of the forbidden: the barred gate, the closed door, the cloister.

The medieval vernacular layout of the historic core is also fairytalesque, forming an impression of what some tourists called 'oldyworldy,' 'medievally' and 'otherworldly' and another, participant Canterbury 24, referred to as: 'the medieval pattern of the city.' The winding motion of central medieval lanes in Canterbury's historic core was unusual to participants used to grid streetscapes, spiralling them deeper into their authentic selves:

Tourist 43: "I find the narrow medieval streets sweet. They give character to Canterbury. They make me feel like wandering around randomly doing nothing, just walking slowly absorbing the positive energy that I perceive around me, walking around the same places where people from medieval times walked by."

Experiential authenticity and magical flow are evident in this comment, as the effects of architectural agency (MacDonald, 2009, p.157) are substantiated by the participant's statement that the streets 'make' her behave in specific ways. Tourists 5, 44 and 48 used a variant of the magical gaze, the 'Grimm gaze,' to discover the "romantic" Hansel and Gretel-style "hidden house" in All Saints Lane, which seemed concealed in plain sight, as Tourist 5 confirmed: "Hidden gem - nice peaceful street that no-one seemed to notice." The agency of the historic environment is further indicated by a pottery "hidden" in the Ginnels (passageways) in Lancaster. As Pullman (2012, pxix) stated: 'A fairytale is 
not a text. The fairytale is in a perpetual state of becoming and alteration' and these photo-diaries evinced a state of magical flow, disclosing the magically quantum activities of historic cities which reassemble themselves, hiding and placing the subconscious in plain view. Space was fluidly creative (Bachelard, 1994; Massey, 2005), revealing and concealing suggestions to tourists.

Participants also considered the "hidden" urban bucolic in Winchester, Shrewsbury and Chester, and Canterbury 6 remarked on a garden in Canterbury Cathedral grounds, the stout, high city walls protecting what became a storied space from the outside world in a manner reminiscent of Oscar Wilde's story of The Selfish Giant. Further folds of historic cities revealed the urban uncanny (Freud, 2004) where the storybook has come to life. Participants photographed the 'English eerie'

(MacFarlane, 2015), the process of medieval entropy encapsulated by the ruins of St Augustine's Abbey and also an overgrown wildflower meadow which houses the seemingly-miniature, ancient Greyfriars Chapel, which was described by Canterbury 1 as: "a last surviving fragment of the Franciscan monastery."

Magical realism has been linked to uncanny sensations of defamiliarity (Royle, 2003, p.160161) which suggest storybook spaces to tourists authenticating historic places. Photographs of Sir John Boy's House on Palace Street in Canterbury (see image 2), the Little Crooked House on Lancaster Quay and Old Chesil Rectory in Winchester, showed defamiliarised leaning structures with sunken foundations conveying the vertiginous passing of time (Lovell and Bull, 2017, p.33). Tourist 8 observed of Sir John Boy's House that: "My husband thought it could not be real as it was obviously part of a set from Alice in Wonderland." A Wonderlandian subconscious turning of the imagination inside out, can be surmised from the focus on the small doors and gates of the city, as expressed by Canterbury 13, when looking at Mint Yard Gate (see image 3): "Such a small gate made for people a lot smaller than we are now."

Image 3: Mint Yard Gate. 


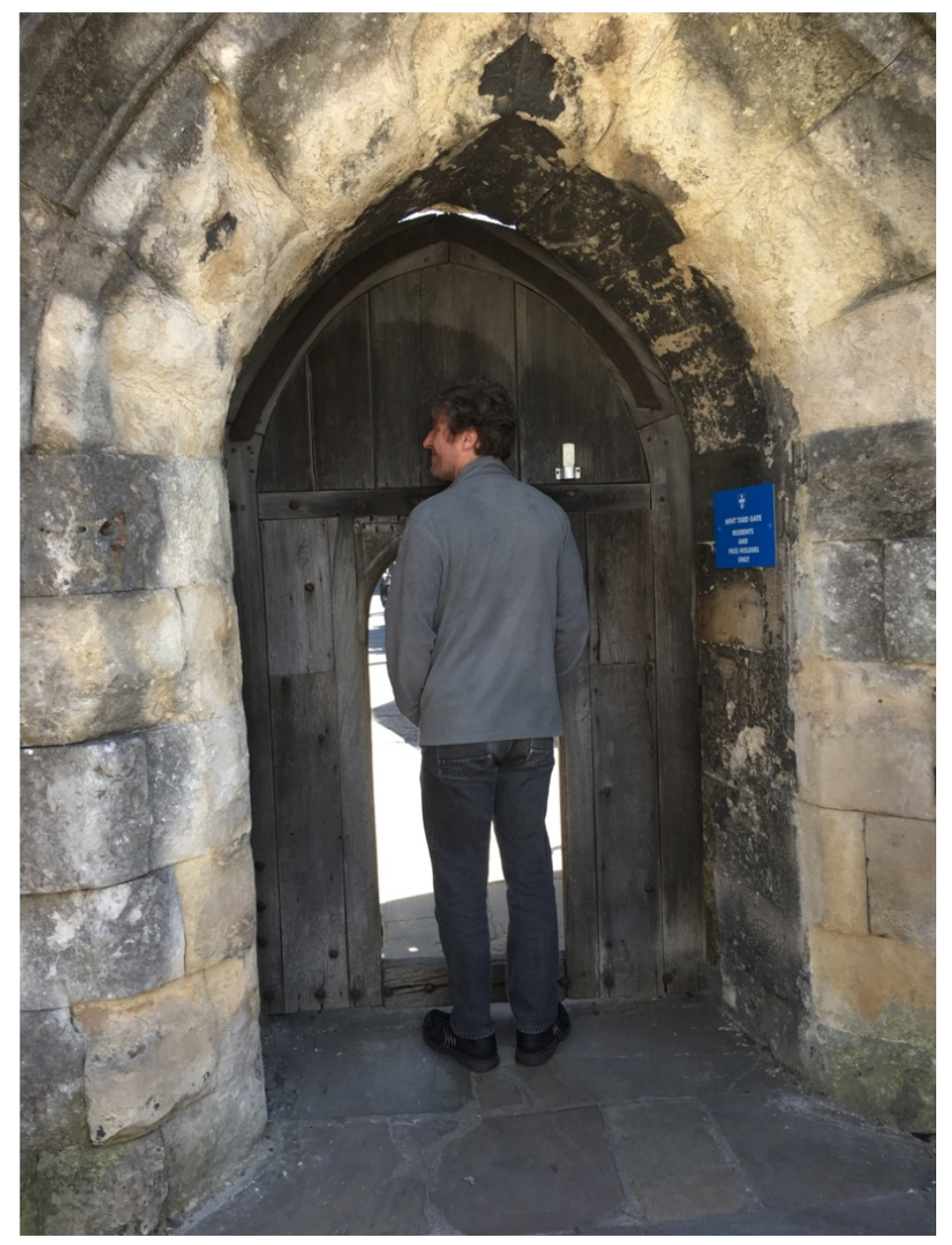

In contrast, some participants considered the exaggerated scale of an outsized pilgrim's inn in Longmarket, Canterbury, dating from 2002. According to participant Canterbury 6, the architects who came to view the building declared: 'It looks Disneyesque!' The magical gaze also observes staged, 'fake real' imitative 'gingerbread architecture' (Hanngian, 1998, p.68). Historic cities are a mixture of original features and new builds and this example of larger-than-life pastiche further entwines the built environment with the fairytalesque, unfolding more Wonderland schemata.

The landscape was augmented by backstories, invented by tourists who detected mysteries. The magical gaze added a veneer of suspense to a trap door for Tourist 44, "Trap door, love the secrecy of where that door leads to." As did some ancient graffiti identified by Canterbury 3: "How authentic is 'Iheny' meaning purity, how old? There is a mystery behind these carefully carved letters." Tourist 28 discovered a mysterious, Harry-Potterish lost diary in the Cathedral cloisters. Both the lost diary and the ancient graffiti acted as examples of the 'punctum,' which Barthes (1980, p2627) described as a poetic, poignant detail which draws the attention in a scene. Hidden houses and streets, tiny doors, oversized and weirdly leaning structures, the punctum of found objects and the single word 'purity,' all combine to suggest the possibilities of the magical gaze.

\section{Fairytale Flâneurie}

Material heritage has the capacity to inspire stories which fill the absences left by time. People-watching and inventing a narrative for strangers is typical flâneur behaviour and fits into Eco's (1986, p.68) concept of the medieval period as a 'mythological stage on which to place contemporary characters.' Fairytales are a genre of folk tales, which portray ordinary people, with similar aims and 
desires (Swann-Jones, 1995, p.9). Crang (2006, p.55) remarked how tourist sites ' ....are shot through by absences, where distant others, removed in spaces and time, haunt the sites.' According to Hemme (2005, p. 75): 'travellers have a need for narratives and imaginaries with which to individually enliven and animate landscapes and thus experience them afresh.' Rather than ghosts, medieval hosts were cast as authentic actors in an imagined mis-en-scène, giving the interplay intersubjective, kinaesthetic immediacy. The experientially authentic state of marvel and wonder at the heritage-marvellous skills of past and contemporary unseen craftsmen, was demonstrated by the York practitioner observing the stained-glass Rose window of the Minster.

The magical gaze made a proscenium arch of windows and gateways framing scenes which occurred throughout the historic cities. When the fairytale consciousness, is raised, it is not simply the Gothic, but all medieval buildings of stone, wood and brickwork possess a viscerally magical carapace, acting as a 'heritage time-turners' (adapted from Harry Potter and the Order of the Phoenix by Lovell and Bull, 2017, p.39), enabling experiential authentication. The fantasy sensation of timetravelling has been established as a commonality of tourism (Laing and Frost, 2012, p.11; RicklyBoyd, 2012, p.129) and was a frequent observation made by many participants: Tourist 42 : "Something that attracts me to Canterbury is that it is a medieval city. And (in a way) I feel transported in time." Time-travelling tourists found that medieval hosts inhabiting metaphysical edgelands where habitual, familiar simple gestures were being repeatedly reinscribed on the space, such as opening windows, passing through gateways, or drinking pints of beer. A picture of an open mullioned window was taken by Tourist 19 (see image 4).

Image 4: Opened mullioned window.

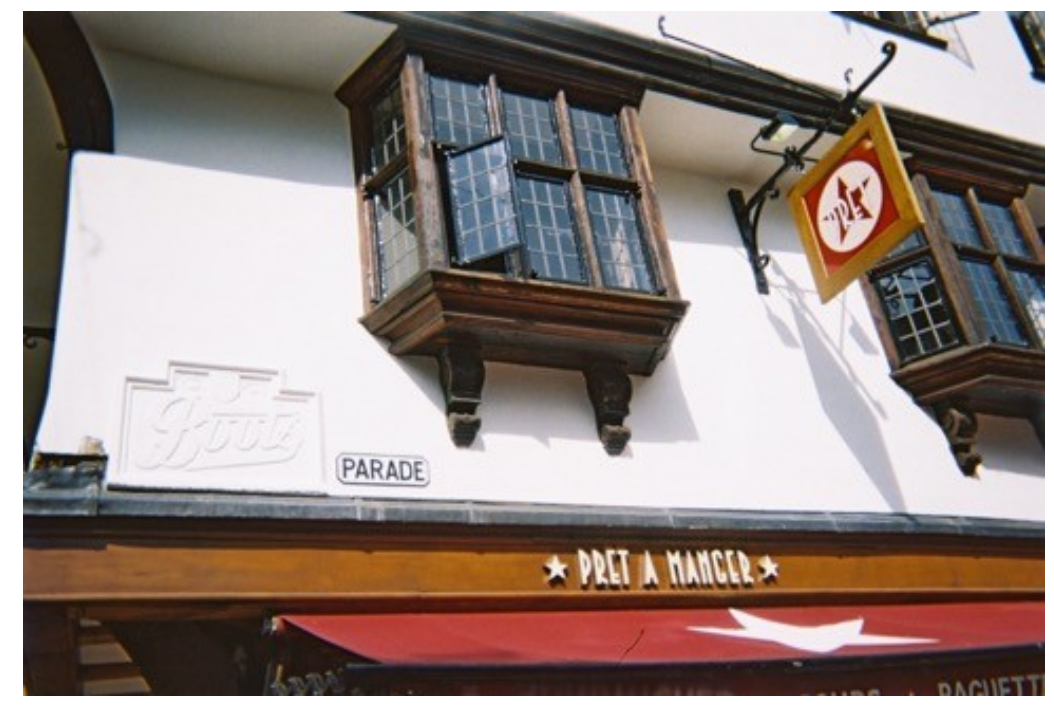

The medieval host was poetically just out of reach; traces of movement in space glimpsed in the peripheral vision, a diffuse presence of a person who had just vanished from view, looking back, occupying the parallel worlds of a Philip Pullman novel.

One participant (Canterbury 9) focused the 'imaginative eye' (Massey, 2005), observing: "Verona type of window. I love this place. You expect Romeo and Juliet to appear." Fantasy literary geographies make popular tourist sites, but of particular relevance to this paper was a comment by a tourism manager in Oxford, whose photo-diary depicted the King's Arms "where the Inklings met." Tolkien wove a 'mythology for England,' using the 'romantic fairy story,' and other interconnected legends (Ortenberg, 2006, p.180). A research participant from Canterbury (9) serendipitously discovered a hint of another pivotal author Boccaccio in Canterbury Cathedral herb garden: "On a hot day, you would be in a Decameron Tale with naughty people in Italian medieval dress behind the wall.” The remark transforms and subverts the peaceful garden with an earthy scene from the 
Decameron, which served as a source for Giovanfrancesco Straparola and Giambattista Basile's authorship of the first stories of the fairytale genre (Swann-Jones, 1995, p.8).

Storytelling is central to flâneurie and participants recast ordinary people as extraordinary fairytale characters; Canterbury 9: "I start the day at Neros at half seven and at a quarter to eight a woman magically appears on the scene with a bundle of medieval clothes and sews there on that sofa and she has to finish a few more stitches." The fairytalesque is implied in the unexplained "magical appearance" of the woman with her bundle of medieval clothes, like the helpers in Anderson's The Elves and the Shoemaker. The woman is also reminiscent of the phrase 'ordinary and then...' (Burness and Griswold, 1982) which was used to describe PL Travers, the writer of Mary Poppins. Probing by the researcher revealed that the woman is a medieval reenactor and sews her costumes in the Tudor café, before work, preparing to inhabit her marvellous heritage another time.

\section{Mythhistoricus}

Fairytales incorporate tall tales (Swann-Jones, 2005, p.11) and the search for authentic backstage views may involve mythmaking, apocryphal tales and urban legends. The magical cultural heritage of historic cities can sometimes resembles staged authenticity when poetic licence is used in order to reinvent cultural heritage for each era. Examples include the $13^{\text {th }}$ century 'round table' hanging in the Great Hall in Winchester, supposedly made for a Round Table Tournament and thought to be Arthurian by Caxton (Ashe, 1991). Tourist (55) pointed out how a tour guide referred to an Inn in Canterbury, staging the unstaged with the words: "Hotel where four knights might have stayed." The Oxford practitioner declared that Oxford "is full of apocryphal stories." Some places seem essentially marvellous, and others are made marvellous, for example, as mentioned earlier, the York practitioner pointed out that the lanes were once called The Great Flesh Shambles because they were an open-air slaughterhouse. Grope Lane in Shrewsbury has also been renamed. What seems to be historic is not always a reliable indicator of authenticity; some subjects are considered too dark to be palatable for modern sensibilities. Sanitising street signs perpetuates a fairytale past, while militating against the unsettling and often crude violence of the fairystory world. While reinterpretations of the past could be said to be forms of staged authenticity (MacCannell, 1973) they contain their own truth; as Chhabra, et al. (2003) observed, '... what is staged is not superficial since it contains elements of the original tradition.' Preserving the myth includes retaining arcane signs as symbols of adventure, an example at the Bell and Crown pub in Canterbury, photographed by Tourist 6: "Vagabonds, dog stealers, horse thieves, rapscallions, scoundrels, liars and especially bursars! Will not be served on these premises!"

The personal narratives of tourists spin history into fairytales, using archetypal characters, such as witches and knights; Tourist 55 described The Weavers, the timbered café beside a (Victorian and therefore fake-medieval) witch's ducking stool as: 'The Dunking House,' 'weaving' their own version. Travellers imbue their journeys with fantasy by using the structures of fiction; a holiday becoming a quest (Laing and Frost, 2012) and dressing up can facilitating a transformation of self, allowing visitors to assume a different identity (Everett and Parakoottathil, 2018). After a family (Tourist 63) had visited the Canterbury Tales visitor attraction, one of the children went on to wear a plastic souvenir knight's helmet throughout the visit; inhabiting the quest.

The seeking of staged authenticity spectacles is illustrated by photo-diaries featuring costumed buskers and re-enactors in medieval clothing in Canterbury, Chester, Rochester and, as the Shrewsbury practitioner described, the 'darker and wilder' Border Morris dancers. Wilder and earthy forms of magic were also embodied in the demonic carvings on a timbered medieval pilgrim's inn (and, reputedly, a brothel) in Mercery Lane observed in Canterbury by Tourist 10 (see image 5).

Image 5: Carving on building in Mercery Lane, Canterbury. 


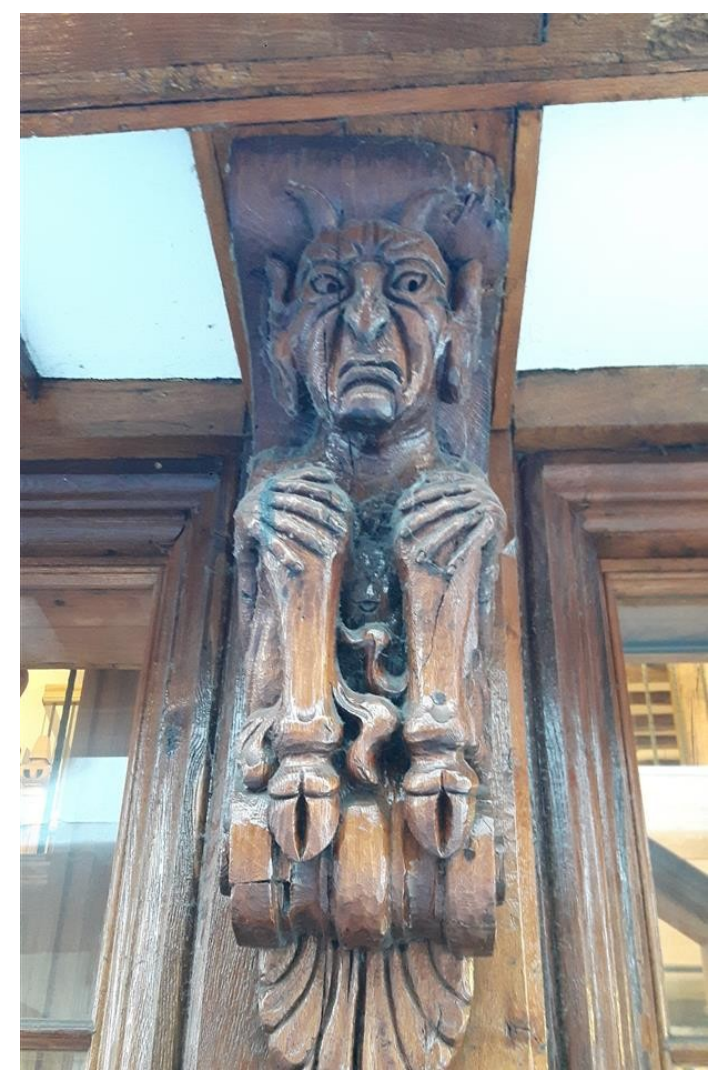

Gargoyles and the green man roof bosses in Canterbury Cathedral (see image 6) provided a mystical, pagan example of magical reality, unfolding the inside of the subconscious to the outside: "There are more than 70 examples of 'green men' sculptures and carvings in Canterbury Cathedral" (Tourist 21).

Image 6: Green man roof boss, Canterbury Cathedral, courtesy of Canterbury Cathedral.

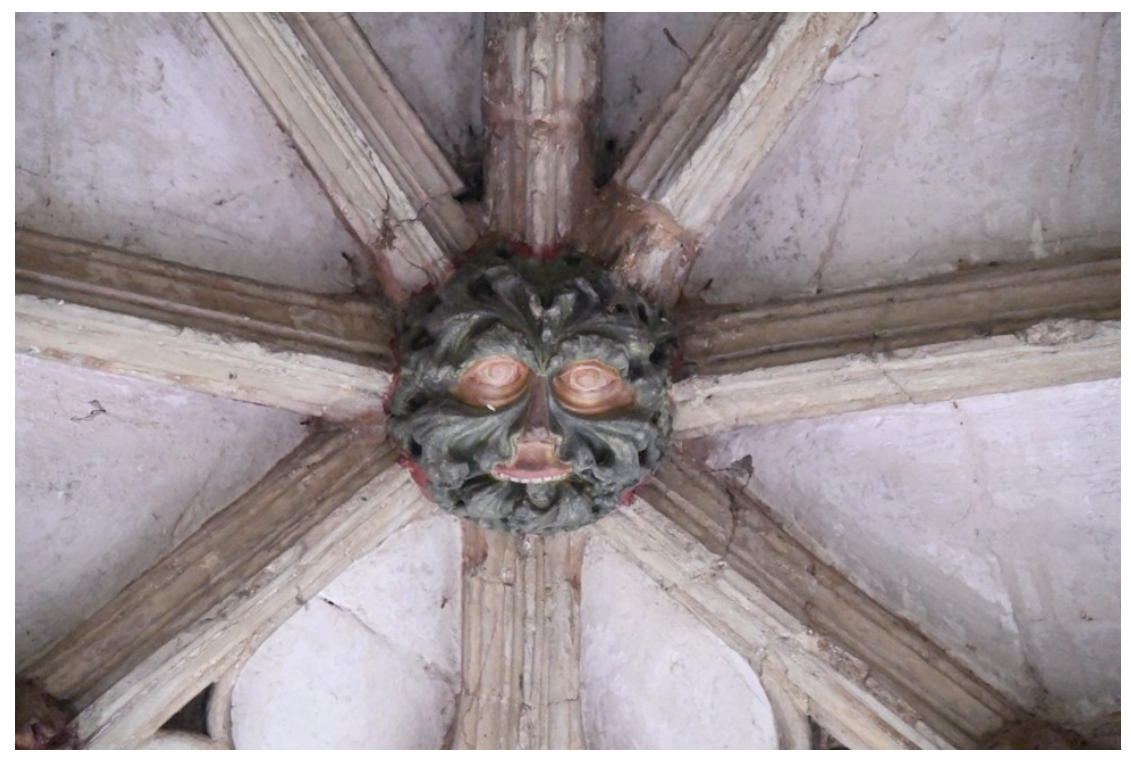

They are also called 'foliate heads' (Larrington, 2015) and depict a mask-like face, surrounded by leaves, with branches sprouting from the mouth. Green men can be found throughout Europe, decorating churches and cathedrals, including Winchester and Cambridge. Fairytales can tap 
into the diffuse atavistic fears, archetypes and deep-seated fears of the subconscious (Freud, 2004) and, as Larrington notes, the story behind this pagan figure is unknown: a mysterious cipher for the imagination. Interestingly, a green man carving above the much-photographed Canterbury chip shop didn't attract the imaginative eye. Unobserved, it is an unexplained presence looking down on the scene. Canterbury Cathedral shop now use the Green Man as a marketing motif, emphasising the mixed myths and sometimes conflicting narratives of heritage buildings.

The research findings bring together elements of fairytale-medievalness, or magi-heritage, in historic cities, (see figure 1) which are stimulated by different forms of built and intangible, recreated, reproduced and revived heritage.

Figure 1: Impressions of fairytale-medievalness in historic cities

Medieval built

environment

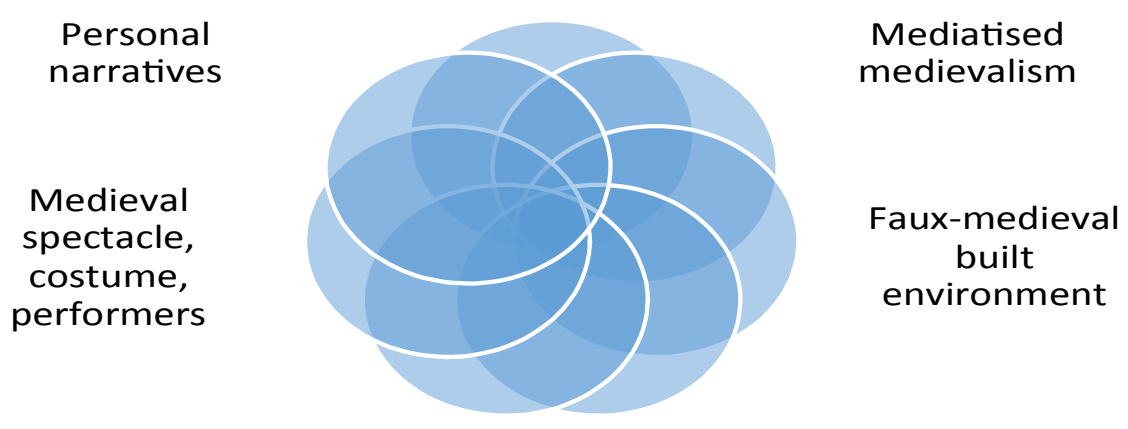

Medieval hosts

Fairytales

Table 1. Impressions of tangible magi-heritage in historic cities.

\begin{tabular}{|l|l|}
\hline Qualities & Illustrated by \\
\hline Fairytale settings & Castles, cathedrals, cottages, lanes \\
\hline Anthropomorphism & Towers, clocks \\
\hline Architectural agency & Winding streets, looming structures, hidden houses and lanes \\
\hline Medieval hosts & Drinking beer, opening windows, buying fruit \\
\hline Scale & Small doors, small chapel \\
\hline Disorientation & Leaning buildings \\
\hline Uncanny & Poignancy of ruins \\
\hline Tall tales & Apocryphal stories in tours, renamed street signs \\
\hline Personal narratives & Dressing up in costume, making up names, inhabiting characters \\
\hline Pagan/folklore & Green man, Morris dancing, devilish carvings \\
\hline Literary fairytale figures & Inklings, Boccaccio \\
\hline Punctum/Mystery & Ancient graffiti, lost diary \\
\hline
\end{tabular}

The findings conclude with a tale of two medieval authenticity palimpsests; the first intangible, the second tangible. The poet Lemn Sissay was asked to write a piece for Canterbury in 2018. Cantuarian used poetic licence to reimagine a knight cleaning his weapons in the River Stour after murdering Thomas Becket, although the events of the night were unknown. The poem was projected onto a bridge spanning the river by Canterbury Cathedral and local Marlowe Theatre in June 2018. The reinscription of the imagined past generates a medieval-fantasy simulacrum (see images 7 and 8) composed of imagination, words, light, brickwork and reflection and the reflected moon in the river is a fairytalesque touch. 
Images 7 and 8: Lemm Sissay's poem: Canturion, projected over the River Stour by the Marlowe Theatre in Canterbury. Courtesy of Griffin.
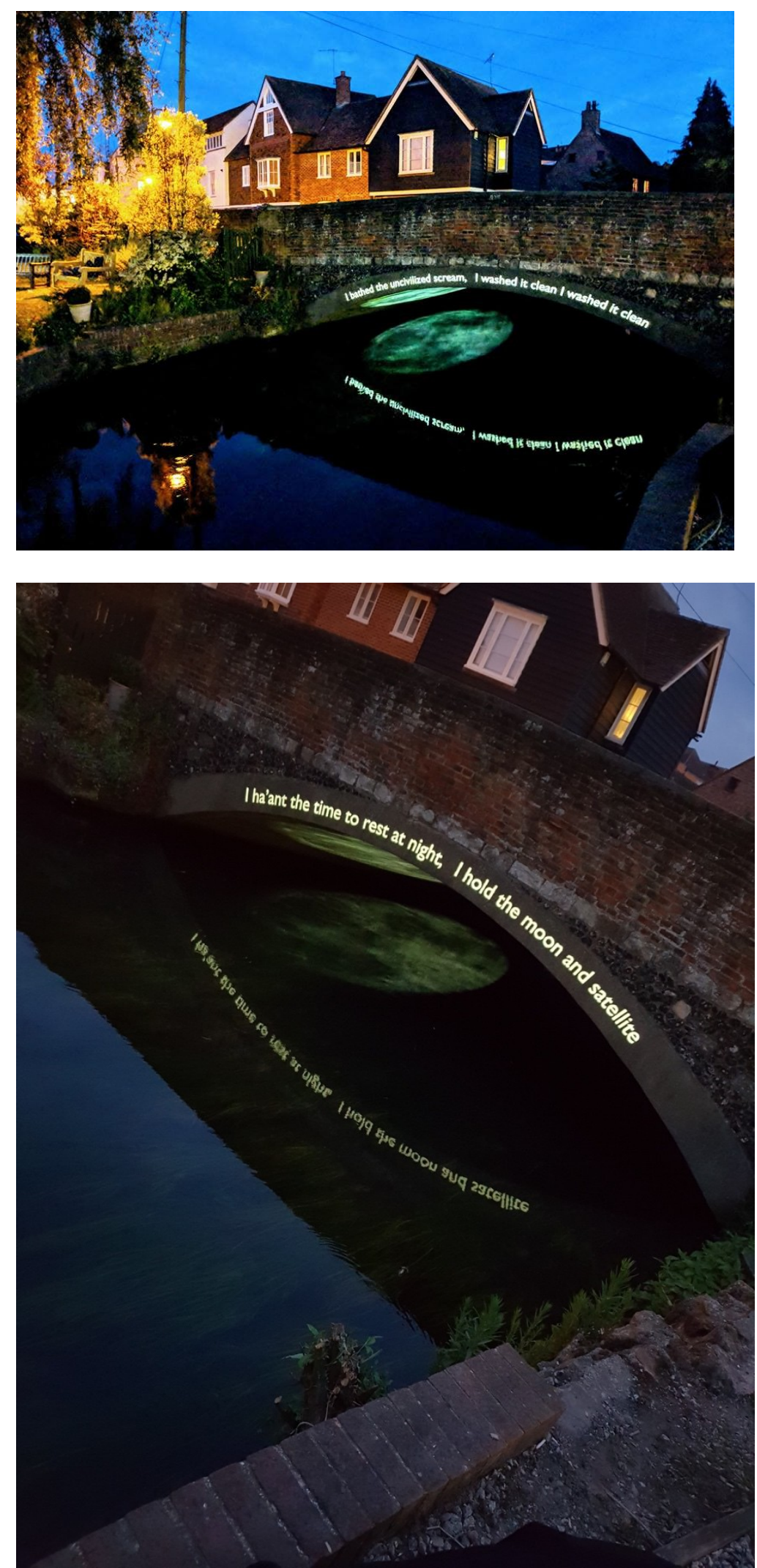

The second example is a marvellous medieval metaphor. As observed by Canterbury (21), a pinnacle and buttress on the North Side of Canterbury Cathedral has "a Romanesque base, with Early 
English, Early Gothic, Later Gothic interventions, then a 1920's and 1930's version of Gothic, which borders on Art Deco." The whole is an assemblage of styles, holding up an iconic building and, when viewed with a magical gaze, adds up to a spectacular tall tale of fairytale-medievalness.

\section{Conclusion}

The research findings indicate that the magical gaze offers an imaginative way of authenticating heritage environments with fairytale schemata. The medieval topology of historic cities may be perceived as innately fairytalesque, suggesting that the blend of magi-heritage is becoming less separate for tourists. 'Fairytale qualities' have been attributed by tourists to the Island of Fyn in Denmark, the birthplace of Hans Christian Andersen (Knudsen and Greer, 2010, p.95), and the increasing popularity of the fantasy medieval landscape indicates that a similar associative process is likely to increase in historic cities. The separation between magical and actual worlds were less marked in historic cities than in theme parks and tourists located the fantasy without signposting. Through affective intentionality, photo-diaries revealed spatial fairytales, the magical gaze of participant and researcher unlocking the intersubjective flow of storybook tropes of looming castles and winding streets. When magic and material heritage aligned in historic cities, some participants assumed an optimal state of magical flow, turning historic cities inside out, perceiving the collective imagination under the stones. Other experientially imaginative states included the Grimm gaze which located the hidden cottage and lane and authenticated historic cities by locating them within fairytale landscapes, such as Alice in Wonderland. Fairytale flâneurie subverted the auratic remoteness of the past, permitting participants to glimpse a parallel world of medieval hosts, as they walked through gates, opened windows, ate and drank, depicting the extraordinary ordinariness of folk-tales. This past and present mis-en-scène is interspaced with folkloric Green Men, pagan dancing and demonic gargoyles. Postmodern authenticities were apparent in the playfully-observed apocryphal stories, fake-real pastiche architecture and sanitised, revised street signage, perpetuating a fairytale version of the past without crude violence.

A limitation of this research is that it initially emerged as distinctive thread from a study of staged authenticity in the historic environment. The authenticity of magi-heritage merits further specific research; the enduring rootedness of fairytales such as Harry Potter implies that locating the fantasy in medieval historic cities may become less serendipitous and more purposeful, not simply for folklore and fairytale tourists, but for heritage tourists. Oxford's magical success will inevitably be replicated, and future research directions could explore extra-textual magical heritage by investigating the effect of magical placemaking (the growth of themed wizarding shops and zones in historic alleyways) on the aura of historic cities. Chhabra et al.'s (2003) view that staged authenticity contains refractions of the originals could be explored in the context of how these extratextual magical geographies are authenticated in varying degrees by placemakers and their fans.

Finally, the sheer pervasiveness of storyworlds is encapsulated in a last example. The author took a class of 37 Level 4 events management students on a walking seminar in Canterbury in September 2018. The group paused in Mercery Lane to examine the grotesque carvings (see image 5) the jetties overhead, the hanging signs and cobblestones underfoot. When asked "What does this lane make you think of?" The class responded: "Harry Potter."

\section{Bibliography}

Ashe, G. (1991). Winchester. In Lacy, N.J., Ashe, G., Ihle, S.N., Kalinke, M.E. and

Thompson, R.H. (Eds.), The New Arthurian Encyclopedia: New Edition. New York, NY: Routledge. Ashworth, G. and Tunbridge, J. (2000). The Tourist-Historic City. Second Edition. London:

Belhaven.

Bachelard, G. (1994). The Poetics of Space. Massachusetts: Beacon Press.

Barthes, R. (2000, first published 1980). Camera Lucida. London: Vintage.

Baudrillard, J. (1981). Selected Writings: Simulacra and Simulation. Cambridge: Polity Press

Beeton, S. (2016). Film-induced tourism. Bristol: Channel view publications. 
Bendix, R., \& Hemme, D. (2004). Fairytale activists: narrative imaginaries along a German tourist route. Folkloreostika svetur, 21, 187-197.

Benjamin, W. $(1936,2008)$. The Work of Art in the Age of Mechanical Reproduction. London:

Penguin.

Bowers, (2004). Magic(al) Realism. Abingdon: Routledge

Boyer, M. (1996). The City of Collective Memory: Its Historical Imagery and architectural

Entertainments. USA: MIT Press

Bruner, E. (1994). Abraham Lincoln as Authentic Reproduction: A Critique of Postmodernism.

American Anthropologist, 96, 397-415.

Buchmann, A., Moore, K. and Fisher, D. (2010). Experiencing film tourism: Authenticity \& fellowship. Annals of Tourism Research, 37(1): 229-248.

Burness, E., \& Griswold, J. (1982). P. L. Travers, The Art of Fiction No. 63. Retrieved from https://www.theparisreview.org/interviews/3099/p-1-travers-the-art-of-fiction-no-63-p-1-travers Carnegie, E., \& McCabe, S. (2008). Re-enactment events and tourism: Meaning, authenticity and identity. Current Issues in Tourism, 11(4), 349-368.

Chhabra, D. (2010). Back to the past: A sub-segment of Generation Y's perceptions of authenticity. Journal of Sustainable Tourism, 18(6), pp.793-809.

Chhabra, D., Healy, R. and Sills, E. (2003). Staged authenticity and heritage tourism. Annals of tourism research, 30(3), 702-719.

Coffrey (2017) Lyra's Oxford: New Philip Pullman-inspired walking tour launches to celebrate book of Dust trilogy. https://www.independent.co.uk/travel/uk/lyras-oxford-walking-tour-philippullman-book-of-dust-trilogy-la-belle-sauvage-northern-lights-his-a8005131.html Accessed 26 December, 19:19.

Cohen, E. (1988). Traditions in the sociology of tourism. Annals of Tourism Research, $15,29-46$.

Collier, M. (2001). Approaches to Analysis in Visual Anthropology. In Van Leeuwen, T., \& Cornford, F.M. (2014). Thucydides Mythistoricus. (Routledge Revivals). Abingdon: Routledge. Crang, M. (1996). 'Magic Kingdom or a Quixotic Quest for Authenticity? Annals of Tourism Research, 23 (2), 415-431.

Debord, G. (1967 \& 2014). The Society of the Spectacle. (Knabb, K. Trans.). Berkley, CA: Bureau of Public Secrets.

Deleuze, G. 2006, 1993). The Fold: Leibniz and the Baroque. (Trans. Conley) London: Continuum Derrida, J. (2016, 1976). Of Grammatology. (Trans. Chakravorty-Spivak). Baltimore, MA: Johns Hopkins University Press.

Dodman D. (2003). Shooting in the City: A VEP Exploration of the Urban Environment in Kingston, Jamaica. Area, 35, 293-304.

Eco, U. (1986). Faith in Fakes: Travels in Hyperreality. London: Picador.

English Heritage (2017) Retrieved from

http://www.english-heritage.org.uk/about-us/search-news/ghost-stories-inspired-by-english-heritage$\underline{\text { sites }}$

Everett, S., \& Parakoottathil, J. (2018). Transformation, meaning-making and identity creation through folklore tourism: the case of the Robin Hood Festival. Journal of Heritage Tourism, 13(1), $30-45$.

Faris, W. (2004). Ordinary Enchantments: Magic Realism and the Remystification of Narrative. Nashville, TN: Vanderbilt University Press.

Fjellman, S. (1992). Vinyl Leaves: Walt Disney World and America. Boulder, CA: Westview Press, Inc.

Freud, S. (2004, first published 1940). The uncanny. In Sandner, D. (Ed.), Fantastic literature: a critical reader. Westport, CT: Greenwood Publishing Group. (pp 74-101).

Guba \& Lincoln, Y. (2008). Paradigmatic Controversies, Contradictions and emerging Confluences. In Denzin, N.K. \& Lincoln, Y.S. (Eds.), The landscape of qualitative research (Vol. 1). London: Sage.

Hemme, D. (2005). Landscape, fairies and identity: Experience on the backstage of the fairytale route. Journal of Tourism and Cultural Change, 3(2), 71-87.

Hobsbawm, E. and T. Ranger (Eds.) (1983). The Invention of Tradition. Oxford: Blackwell. 
Olivia Jenkins, 'Photography and Travel Brochures: The Circle of Representation.' Tourism geographies 5.3 (2003): 305.

Kim, H., \& Jamal, T. (2007). Touristic quest for existential authenticity. Annals of Tourism Research, 34(1), 181-201.

Knudsen, D., \& Greer, C. (2011). Tourism and nostalgia for the pastoral on the island of Fyn, Denmark. Journal of Heritage Tourism, 6(2), 87-98.

Knudsen, D.C., Rickly, J.M. and Vidon, E.S. (2016). The fantasy of authenticity: Touring with Lacan. Annals of Tourism Research, 58, 33-45.

Larrington, C. (2015). The land of the green man: a journey through the supernatural landscapes of the British Isles. London: IB Tauris.

Larrington, C. (2016). Winter is coming: The medieval world of Game of Thrones. London: I.B. Tauris.

Järv, R. (2010). Fairytales and tourist trips. Fabula, 51(3-4), 281-294.

Laing, J. and Frost, W. (2012). Books and Travel. Bristol: Channel View Publications.

Larsen, J. (2008). 'Practices and Flows of Digital Photography: An Ethnographic Framework,'

Mobilities, 3, (1), 141-160.

Leal, L. (1995). Magic Realism in Spanish America. In Zamora, L.P. \& Faris, W. (Eds.), Magic

Realism: Theory, History, Community. London: Duke University Press.

Lovell, J. (2018). Hyperreal Light Simulacra: Performing Heritage Buildings. In Rickly, J. \& Vidon, E. (Eds.), Authenticity \& Tourism: Materialities, Perceptions, Experiences. Dublin: Emerald. Lovell, J., \& Bull, C. (2017). Authentic and Inauthentic Places in Tourism: From Heritage Sites to Theme Parks. Abingdon: Routledge.

Lovell, J. and Griffin, H. (2018). Fairy tale tourism: the architectural projection-mapping of irreal and magically real lightscapes. The Journal of Policy Research in Tourism, Leisure and Events https://doi.org/10.1080/19407963.2018.1556674

MacCannell, D. (1973). Staged authenticity: Arrangements of social space in tourist settings. The American Journal of Sociology, Vol. 79, No.3: 589-603.

MacCannell, D. (1976). The Tourist: A New Theory of the Leisure Class. New York, NY: Schocken Books.

MacDonald, S. (2009). Difficult Heritage: Negotiating the Nazi Past in Nuremberg and Beyond. Abingdon: Routledge.

MacFarlane, R. (2015, April 10) The Eeerieness of the English Countryside. Retrieved from https://www.theguardian.com/books/2015/apr/10/eeriness-english-countryside-robert-macfarlane Macionis, N. (2004) Understanding the film-induced tourist. In Croy and S. Beeton (Eds.) Proceedings of the International Tourism and Media Conference, pp. 86 - 97. Melbourne: Tourism Research Unit, Monash University.

Massey, D. (2005). For Space. London: Sage.

Nora, P. (1984-1992). Les Lieux de Memoire. Paris: Gallimard.

Orbaşli, A. (2000) Tourists in Historic Towns: Urban Conservation and Heritage Management. London: Taylor and Francis.

Ortenberg, V. (2006). In search of the Holy Grail: The quest for the Middle Ages. London: A\&C Black.

Pink, S. (2006). The future of visual anthropology: Engaging the senses. Abingdon: Routledge.

Pullman, P. (2012). Grimm Tales for Young and Old. London: Penguin Classics.

Shiel M., \& Fitzmaurice T. (2001). Cinema and the City: Film and urban studies in a global context. Oxford: Blackwell Publishers.

Relph, E. (1976). Place and Placelessness. London: Pion Ltd.

Rickly-Boyd, J.M. (2012) 'Through the magic of authentic reproduction': tourists' perceptions of authenticity in a pioneer village. Journal of Heritage Tourism, 7(2): 127-144.

Robinson, M., \& Picard, D. (2009). Moments, magic and memories: Photographing tourists, tourist photographs and making worlds. In Picard, D. and Robinson, M. (Eds.), The Framed World: tourism, tourists and photography. Routledge. (pp.1-37).

Royle, N. (2003). The Uncanny. Manchester: Manchester University Press.

Sartre, J.P. (2004). The imaginary: A Phenomenological psychology of the imagination. (Webber, J. Trans.). London: Routledge. 
Self, W. (2007). Visit to Waterstone's Canterbury. Author present.

Sissay, L. (2018). Cantuarian. Retrieved from: https://www.canterbury-cathedral.org/whats-on/news/ 2018/06/12/a-poem-for-canterbury/

Smith, L. (2006). Uses of Heritage. Abingdon: Routledge.

Stevenson, N., \& Inskip, C. (2008). Visualising London. London Journal of Tourism, Sport and Creative Industries, 1(1), 3-12.

Strecher, M.C. (1999). Magical realism and the search for identity in the fiction of Murakami Haruki. Journal of Japanese Studies, Vol 25, (2), 263-298.

Swann, J.S. (1995). The Fairy Tale-The Magic Mirror Of Imagination. New York, NY: Wayne Publication.

Thomas, J. (1986). Woods and castles, towers and huts: Aspects of setting in the fairy tale. Children's Literature in Education, 17(2), 126-134.

Timothy, D.J. (2011). Cultural heritage and tourism: An introduction. Bristol: Channel View

Publications.

Tuan, Y. (2001, first published 1977). Space and Place (Reprint Ed.). Minneapolis, MN: University of Minnesota Press.

Urry, J. (2002). The Tourist Gaze. (2nd ed.). London: Sage.

Wang, N. (1999). Rethinking authenticity in tourism experience. Annals of Tourism Research, Vol. 26, (2): 349-370.

Waysdorf, A. and Reijnders, S. (2018). Immersion, authenticity and the theme park as social space: Experiencing the Wizarding World of Harry Potter. International Journal of Cultural Studies, 21(2): 173-188.

Willson, G.B., \& McIntosh, A.J. (2007). Heritage buildings and tourism: An experiential view. Journal of Heritage Tourism, 2(2), 75-93.

Yellowbook (2005). Canterbury: City of imagination. Canterbury City Council.

Zipes, J. (1988). The Brothers Grimm: From Enchanted Forests to the Modern World. London: Routledge. 